\title{
PENGEMBANGAN PERANGKAT BLENDED LEARNING BERBASIS LEARNING MANAGEMENT SYSTEM PADA MATERI LISTRIK DINAMIS
}

\author{
Winda Wijayanti ${ }^{1}$, Nengah Maharta ${ }^{2}$, Wayan Suana ${ }^{3}$ \\ 1, 2, 3 Pendidikan Fisika, FKIP Universitas Lampung, Jl. Sumantri Brojonegoro No.1 Bandar Lampung, Indonesia \\ Email: windawijayanti8@gmail.com
}

Diterima: 2 Maret 2017. Disetujui: 11 April 2017. Dipublikasikan: 28 April 2017

\begin{abstract}
Abstrak: Tujuan dari penelitian ini adalah untuk menghasilkan perangkat blended learning berbasis LMS dengan model inkuiri pada materi listrik dinamis, mengetahui validitas produk yang dikembangkan. Penelitian ini mengacu pada prosedur penelitian dan pengembangan dari Gall et al., (2003) yang meliputi studi pendahuluan, perancangan program dan pengembangan program. Pada tahap studi pendahuluan dilakukan di SMA N 1 Gadingrejo. Pada tahap perancangan produk dilakukan pembuatan perangkat blended learning yang meliputi silabus, RPP, LKPD, handout dan kelas online dengan LMS Schoology. Pada tahap pengembangan produk dilakukan dilakukan uji ahli untuk menilai validitas produk. Hasil menunjukkan bahwa validitas produk sebesar $83,7 \%$ dan $84,8 \%$ dari penilaian dua orang ahli. Berdasarkan hasil penelitian ini maka disimpulkan bahwa perangkat blended learning memiliki validitas yang sangat baik sebagai perangkat pembelajaran pada materi pokok listrik dinamis.
\end{abstract}

Kata kunci: blended learning, learning management system, listrik dinamis, schoology.

\section{DEVELOPMENT OF BLENDED LEARNING DEVICES BASED ON LEARNING MANAGEMENT SYSTEM IN DYNAMIC ELECTRIC MATERIAL}

\begin{abstract}
This paper describes the process of designing LMS-based blended learning for electrodynamics topic and describing its validity. The study implemented research and development model of Gall et al. (2013) which consists of three main stages; preliminary research, product design, and product development. Preliminary research was conducted at SMAN 1 Gadingrejo. Blended learning sets produced in this study were syllabus, lesson plan, students' worksheet, handout and online class by LMS Schoology. In the product development process, expert judgment was done to assess validity of the product. The results showed that the blended learning set had validity of $83,7 \%$ and $84,8 \%$ from two experts. Based on these results, it can be concluded that blended learning set has very good validities as learning set of electrodynamics topics.
\end{abstract}

(C) 2017 Pendidikan Fisika FTK UIN Raden Intan Lampung

Keywords: blended learning, learning management system, electrodynamic, schoology.

\section{PENDAHULUAN}

Menghadapi perkembangan zaman yang semakin pesat pada Abad 21, maka pembelajaran harus dirancang agar dapat mencapai kompetensi Abad 21. Salah satu dari enam unsur pembelajaran abad 21 (Partnership for 21st century skills, 2002) adalah literasi informasi dan literasi TIK. Agar kemampuan literasi informasi dan literasi TIK peserta didik juga berkembang maka integrasi TIK dalam pembelajaran perlu dilakukan.
Peningkatan kompetensi literasi informasi dan literasi TIK peserta didik secara efektif dapat dilakukan dengan cara mengintegrasikan TIK termasuk internet sebagai alat dalam proses pembelajaran (Yilmaz \& Orhan, 2012).

Kompetensi Abad 21 juga menuntut agar peserta didik terlibat langsung dalam proses pembelajaran yang memanfaatkan fasilitas internet, dimana peserta didik bukan hanya sebatas mencari informasi, tapi peserta didik juga melaksanakan 
pembelajaran secara online. Dengan begitu keterampilan literasi TIK dan literasi informasi peserta didik akan tergali.

Kenyataannya masih ditemui dikalangan pendidik belum memanfaatkan fasilitas internet secara maksimal, hal tersebut jelas bertolak belakang dengan tuntutan kompetensi abad 21. Kompetensi abad 21 yang juga didukung oleh kurikulum 2013 yang mengedepankan keaktifan peserta didik. Sehingga berdasarkan hal tersebut pendidik harus mampu mendesain sistem pembelajaran yang mampu memotivasi dan meningkatkan keterampilan TIK peserta didik.

Begitu juga dengan pembelajaran fisika, sistem pembelajaran yang dirancang guru harus mampu meningkatkan motivasi dan literasi TIK siswa sebagai tuntutan kompetensi Abad 21. Selain itu sistem tersebut diharapkan mampu mengentaskan masalah kesulitan yang dialami peserta didik dalam pembelajaran fisika. Materi fisika terbilang materi yang sulit, hal tersebut sesuai dengan tanggapan yang diberikan oleh siswa pada sebaran angket yang diberikan oleh peneliti.

Selain untuk mengatasi kesulitan peserta didik dalam pemahaman konsep, meningkatkan literasi TIK peserta didik, desain yang dirancang juga harus mampu mendongkrak dan memunculkan minat belajar peserta didik. Salah satu model pembelajaran yang dapat diterapkan adalah model pembelajaran inkuiri. Inkuiri merupakan suatu proses dan mendapatkan suatu informasi dengan melakukan observasi atau eksperimen untuk mencari suatu jawaban atau memecahkan masalah terhadap pertanyaan atau rumusan masalah pada kegiatan penyelidikan terhadap objek pertanyaan (Ibrahim, 2010).

Kelebihan dalam menerapkan model pembelajaran inkuiri antara lain real life skill, openended topic, intuitif, imajinatif, inovatif, dan peluang melakukan penemu- an melalui observasi dan eksperimen (Anam, 2016), motivasi peserta didik terhadap pembelajaran sains dapat meningkat (Justice et al., 2009). Namun disamping kelebihannya, model inkuiri memliki kelemahan salah satunya adalah memerlukan waktu yang cukup panjang (Hamruni, 2011). Hal tersebut juga sesuai dengan pendapat salah satu guru fisika kelas XII di SMA ke-1 bahwa salah satu kesulitan yang dialami guru yaitu kekurangan waktu atau dengan kata lain alokasi waktu yang disediakan tidak sebanding dengan tujuan pembelajaran yang harus dicapai.

Untuk mengatasi kekurangan waktu karena waktu yang diperlukan cukup panjang, pembelajaran inkuiri dapat dilaksanakan dengan menggabungkan pembelajaran tatap muka dan online learning, atau disebut dengan blended learning. Mosa (2006), menyatakan bahwa yang dikombinasikan adalah dua unsur utama, yakni pembelajaran di kelas dengan tatap muka dengan pembelajaran seacar online. Kombinasi tersebut biasa disebut dengan blended learning (pembelajaran campuran). Salah satu tipe yang dapat digunakan yaitu tipe online - tatap muka - online.

Untuk melaksanakan pembelajaran secara blended, diperlukan suatu aplikasi yaitu learning management system(LMS). Learning Management System (LMS) merupakan suatu aplikasi atau software yang digunakan untuk mengelola pembelajaran online yang meliputi beberapa aspek yaitu materi, penempatan, pengelolaan, dan penilaian (Mahnegar, 2012).

Salah satu syarat penggunaan LMS dalam proses pembelajaran, pendidik dan peserta didik harus terkoneksi dengan jaringan internet yang memadai. LMS memiliki beberapa fitur yang mendukung proses pembelajar-an online, misalnya forum diskusi, kurikulum sumber belajar, kuis, tugas, jenis informasi akademik, dan pengelolaan data siswa. 
Terdapat beberapa jenis LMS yang dapat dimanfaatkan dalam proses pembelajaran diantaranya adalah Schoology, Learnboos, Edmodo, Moodle dan lainlain. Amiroh (2013), menyatakan bahwa, kelebihan Schoology dibandingkan dengan LMS lainnya antara lain, Schoology menggunakan istilah-istilah yang biasa kita gunakan pada jejaring sosial facebook, moddle, dan edmodo seperti recent activity, message, course, resource, groups, assignment, dan attendance. Schoology memiliki fasilitasfasilitas yang tidak dimiliki oleh Edmodo dan Moddle.

Sejalan dengan pembelajaran blended learning yang dikembangkan oleh peneliti terdapat beberapa hasil penelitian mengenai blended learning, diantaranya hasil penelitian yang dilakukan oleh Sutisna (2016) yang menunjukan bahwa tingkat kemandirian belajar siswa setelah diterapkan metode blended learning diklasifikasikan dalam kategori baik dengan pola yang digunakan yaitu online - tatap muka - blended sehingga pembelajaran dapat dikatakan berhasil. Keberhasilan suatu proses pembelajaran juga ditunjukkan dengan hasil belajar siswa. Hasil belajar yang baik juga tidak terlepas dari penguasaan konsep yang dimiliki siswa, maka untuk meningkatkan penguasaan konsep siswa dapat dilakukan dengan menerapkan metode blended learning. Hal tersebut sesuai dengan hasil penelitian yang dilakukan oleh Hermawanto et al., (2013). Hal serupa mengenai blended learning juga diungkapkan oleh Purnomo et al., (2016), dengan diterapkannya blended learning dengan desain online - tatap muka peserta didik hampir seluruhnya dapat mengikuti proses pembelajaran dengan baik yang ditunjukkan dengan nilai dan keaktifan di kelas.

Berdasarkan ulasan-ulasan di atas, peneliti mencoba memberikan alternatif sistem pembelajaran yang dapat diterapkan oleh guru dengan mengembangkan perangkat blended learning berbasis LMS dengan model pembelajaran inkuiri pada materi listrik dinamis dengan harapan akan teraplikasi dalam proses pembelajaran dan membantu meningkatkan pemahaman konsep bagi peserta didik serta keterampilan literasi informasi dan literasi TIK peserta didik.

\section{METODE PENELITIAN}

Metode penelitian yang digunakan adalah penelitian dan pengembangan (Research and Development) dari (Gall et $a l ., 2003$ ) dengan sepuluh tahapan dimana peneliti membatasi hingga tahapan ketiga. Pengembangan yang dilakukan oleh peneliti adalah pembuatan media pembelajaran berupa perangkat blended learning berbasis LMS dengan model inkuiri pada materi listrik dinamis. Pembuatan perangkat blended learning ini melalui beberapa tahap, yaitu 1) Studi pendahuluan, 2) Perancangan produk, 3) Pengembangan produk.

\section{Studi Pendahuluan}

Pada tahap ini, akan dilakukan survei lapangan dan kajian pustaka. Survei lapangan dilaksanakan kepada peserta didik SMA N 1 Gadingrejo kelas XII MIPA 3, yaitu mengenai ketersediaan fasilitas internet, pengalaman peserta didik dalam pembelajaran fisika materi listrik dinamis, dan persepsi peserta didik mengenai pembelajaran fisika. Selanjutnya untuk memperoleh data kebutuhan guru dilakukan wawancara terhadap guru fisika kelas XII SMA N 1 Gadingrejo.

\section{Perancangan Produk}

Pada tahap ini akan disusun draf perangkat blended learning berbasis inkuiri. Perangkat yang disusun meliputi desain blended learning berbasis inkuiri, silabus, RPP, LKPD blended learning berbasis inkuiri, handout, latihan soal dan kelas online learning dengan Schoology. Desain blended learning yang dimaksud menyangkut desain pembelajaran campur- 
an berbasis inkuiri, bagian mana yang dilaksanakan secara online dan bagian mana yang dilakukan secara tatap muka, dan bagaimana pembagian waktu dilakukan. Dengan lebih spesifiknya desain blended learning yang digunakan yaitu online learning - tatap muka - online learning. Sedangkan kelas dan konten online learning merupakan perancangan kelas dan kontennya yang dapat dimanfaatkan oleh guru untuk memfasilitasi siswa belajar secara online baik mandiri maupun kolaboratif. Pada kelas online, akan terdapat beberapa bagian. Di mana guru dapat memanfaatkan bagian-bagian tersebut untuk melaksanakan pembelajaran, memberikan tugas dan mengevaluasi siswa.

\section{Pengembangan Produk}

Pada tahap ini, dilakukan uji kevalidan hasil rancangan perangkat melalui uji ahli. Uji validasi ahli dilakukan melalui pengisian angket uji validasi setiap aspek perangkat yang dikembangkan (silabus, RPP, LKPD, handout, soal evaluasi dan kelas online). Setelah uji validasi kepada ahli, dilanjutkan uji kepraktisan kepada tiga orang guru fisika kelas XII dari tiga SMA yang berbeda.

Teknik analisis data uji validasi ahli dan uji kepraktisan. Angket uji validasi diberikan kepada dua orang ahli dengan mengisi pada kolom "1", “2”, “3”, “4”, dan "5". Revisi dilakukan oleh peneliti pada konten pertanyaan yang diberi pilihan jawaban "1" dan " 2 ", atau para ahli memberikan masukan khusus terhadap perangkat yang sudah dibuat. Jihad dan Haris dalam Suradnya (2016) menyatakan kriteria penilaian sebagai berikut:

$$
P=\frac{f}{n} x 100 \%
$$

Keterangan:

$\mathrm{P}$ : persentase kelayakan

f : skor asek

$\mathrm{n}$ : skor maksimum aspek
Setelah mendapatkan persentase penilaian, maka dikonfersikan menjadi nilai kualitas yang dapat dilihat pada Tabel 1 .

Data praktisi produk diperoleh dari uji kepraktisan kepada tiga guru fisika SMA kelas XII MIPA dari tiga sekolah yang berbeda. Angket uji kepraktisan ini memiliki 5 pilihan jawaban sesuai konten pertanyaan, yaitu: "1", “2”, “3","4" dan "5". Penilaian instrumen total dilakukan dari jumlah skor yang diperoleh, kemudian dibagi dengan jumlah total skor tertinggi dan hasilnya dikali dengan banyaknya pilihan jawaban. Skor penilaian tiap pilihan jawaban ini dapat dilihat dalam Tabel 2.

Hasil dari skor penilaian dicari rataratanya dari ketiga guru dan dikonfersikan ke pernyataan penilaian untuk menentukan kualitas. Pengonversian skor menjadi pernyataan kualitas dapat dilihat pada Tabel 3.

Tabel 1. Kriteria Persentase Kelayakan Isi dan Desain Menurut Sugiyono (2010:144)

\begin{tabular}{ccc}
\hline No & Persentase Kelayakan & Kriteria \\
\hline 1 & $80 \%<\mathrm{P} \leq 100 \%$ & Sangat Baik \\
2 & $60 \%<\mathrm{P} \leq 80 \%$ & Baik \\
3 & $40 \%<\mathrm{P} \leq 60 \%$ & Cukup Baik \\
4 & $20 \%<\mathrm{P} \leq 40 \%$ & Kurang Baik \\
5 & $0 \%<\mathrm{P} \leq 20 \%$ & Tidak Baik \\
\hline
\end{tabular}

Tabel 2. Skor Penilaian terhadap Pilihan Jawaban Menurut Suyanto dan Sartinem (2009: 227)

\begin{tabular}{ccc}
\hline Pilihan Jawaban & Pilihan Jawaban & Skor \\
\hline Sangat Praktis & Sangat Baik & 5 \\
Praktis & Baik & 4 \\
Cukup Praktis & Cukup Baik & 3 \\
Kurang Praktis & Kurang Baik & 2 \\
Tidak Praktis & Tidak Baik & 1 \\
\hline
\end{tabular}

Tabel 3.Konversi Skor Penilaian Menjadi Nilai Kualitas Menurut Widyoko (2009: 242)

\begin{tabular}{ccc}
\hline $\begin{array}{c}\text { Skor } \\
\text { Penilaian }\end{array}$ & Rerata Skor & Klasifikasi \\
\hline 5 & $80<\mathrm{X}$ & Sangat Baik \\
4 & $60<\mathrm{X} \leq 80$ & Baik \\
3 & $40<\mathrm{X} \leq 60$ & Cukup Baik \\
2 & $20<\mathrm{X} \leq 40$ & Kurang Baik \\
1 & $\mathrm{X} \leq 20$ & Tidak Baik \\
\hline
\end{tabular}




\section{HASIL DAN PEMBAHASAN Hasil}

Hasil penelitian pengembangan yang dilakukan adalah berupa perangkat blended learning berbasis LMS dengan model inkuiri pada materi listrik dinamis. Tahapan-tahapan pada penelitian ini yaitu: (1) Studi Pendahuluan, (2) Perancangan Produk, dan (3) Pengembangan Produk. Adapun ulasan dari tiap tahapan penelitian sebagai berikut:

\section{Studi Pendahuluan}

Data studi pendahuluan diperoleh dari wawancara untuk menganalisis kebutuhanguru fisika kelas XII SMA N 1 Gadingrejo. Tahap Analisis kebutuhan dilakukan diawal penelitian untuk mencari informasi supaya masalah yang sedang diteliti memiliki kedudukan yang jelas (Arikunto, 2013). Hasil wawancara ditampilkan pada Tabel 4.

Selain data diperoleh dari wawancara kepada guru, data studi pendahuluan juga diperoleh dari hasil penyebaran angket kepada siswa kelas XII MIPA 3 SMA N 1 Gadingrejo. Rekapitulasi hasil angket siswa ditunjukkan pada Tabel 5.

Tabel 4. Rekapitulasi Hasil Wawancara

\begin{tabular}{|c|c|c|}
\hline No & Aspek & Identifikasi Masalah \\
\hline 1 & Akses internet & $\begin{array}{l}\text { Frekuensi penggunaan internet yang dilakukan oleh guru } \\
\text { dapat dikatakan sering, namun belum diterapkan pada } \\
\text { peserta didik. }\end{array}$ \\
\hline 2 & $\begin{array}{l}\text { Pembelajaran pada meteri } \\
\text { listrik dinamis }\end{array}$ & $\begin{array}{l}\text { Materi listrik dinamis termasuk dalam materi yang sulit } \\
\text { dan membutuhkan waktu yang relatif panjang dalam } \\
\text { penyampaiannya sehingga guru mengalami kekurangan } \\
\text { waktu. } \\
\text { Metode yang digunakan guru cenderung sama dari } \\
\text { waktu ke waktu yakni metode latihan soal dan } \\
\text { eksperimen. }\end{array}$ \\
\hline 3 & Media pembelajaran & Media yang digunakan guru sejauh ini hanya LKS \\
\hline 4 & Kenadala yang dihadapi & $\begin{array}{l}\text { Alokasi waktu yang disediakan tidak dapat mencapai } \\
\text { tujuan pembelajaran, karena materi listrik dinamis } \\
\text { termasuk materi yang sulit jadi dibutuhkan waktu yang } \\
\text { cukup panjang dalam menyampaikannya. }\end{array}$ \\
\hline
\end{tabular}

Tabel 5. Rekapitulasi Hasil Angket Siswa

\begin{tabular}{|c|c|c|}
\hline No & Aspek & Identikasi Masalah \\
\hline 1 & $\begin{array}{l}\text { Kesulitan dalam } \\
\text { pembelajaran listrik } \\
\text { dinamis }\end{array}$ & $\begin{array}{l}\text { Sebesar } 65,6 \% \text { siswa mengalami kesulitan dalam } \\
\text { pembelajaran fisika khususnya listrik dinamis }\end{array}$ \\
\hline 2 & $\begin{array}{l}\text { Pemanfaatan internet oleh } \\
\text { siswa }\end{array}$ & $\begin{array}{l}\text { Sebagian besar siswa yakni sebesar } 87,5 \% \text { siswa } \\
\text { mengakses bahan ajar fisika dari situs web di internet }\end{array}$ \\
\hline 3 & $\begin{array}{l}\text { Keterampilan siswa dalam } \\
\text { menggunakan TIK }\end{array}$ & $\begin{array}{l}\text { Sebesar } 87,5 \% \text { siswa terampil dalam menggunakan TIK } \\
\text { dan sebesar 93,8\% siswa tidak mengalami kesulitan } \\
\text { dalam menggunakan TIK }\end{array}$ \\
\hline 4 & $\begin{array}{l}\text { Pengalaman belajar siswa } \\
\text { secara online }\end{array}$ & $\begin{array}{l}\text { Sebanyak } 96,9 \% \text { siswa tidak pernah melakukan } \\
\text { pembelajaran secara online di internet } \\
\text { sebesar } 96,9 \% \text { siswa mengatakan bahwa guru belum } \\
\text { pernah melakukan evaluasi pengembelajaran secara } \\
\text { online } \\
84,4 \% \text { siswa mengatakan belum pernah mendapatkan } \\
\text { bahan ajar dari guru yang diunggah di situs internet }\end{array}$ \\
\hline
\end{tabular}


Berdasarkan hasil analisis kebutuhan yang dilakukan kepada guru dan peserta didik maka keadaan tersebut sangat mendukung dikembangkannya perangkat pembelajaran blended learning.

\section{Perancangan Produk}

Pada tahap ini dilakukan perancangan atau pembuatan produk. Produk yang dikembangkan berupa perangkat pembelajaran blended learning yang terdiri dari silabus, RPP, LKPD, handout, soal latihan dan kelas online. LKPD yang dibuat dibagi menjadi 5 kegiatan pembelajaran, dengan setiap kegiatan dibagi menjadi tiga kegiatan pokok yaitu online - tatap muka - online. Tiga kegiatan pokok atau yang disebut tipeblended learning yang digunakan dapat dilihat pada Gambar 1 (Maharta, et al., 2016).

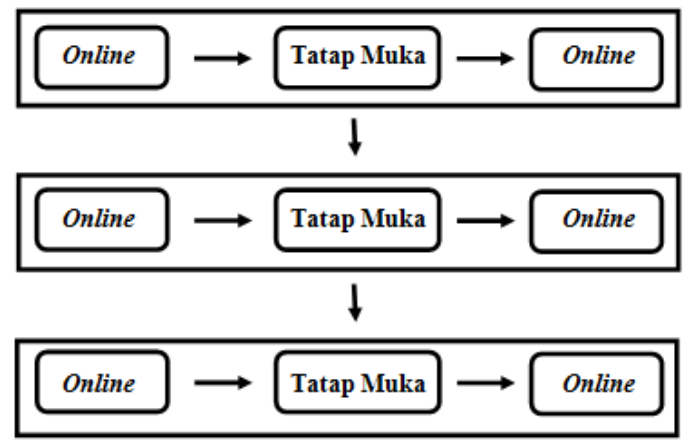

Gambar 1. Desain blended learning

Pada setiap kegiatan yang tertera pada Gambar 1 akan dilakukan tahapantahapan inkuiri. Kegiatan online pra-tatap muka beisi kegiatan pengamatan fenomena, pembuatan rumusan masalah dan pengajuan hipotesis serta pemahaman awal mengenai materi yang akan diajarkan. Pada kegiatan tatap muka terdapat kegiatan pengumpulan data, analisis data, penarikan kesimpulan dan kegiatan diskusi. Kemudian pada tahap akhir yaitu online pasca tatap muka dilakukan untuk memberikan soal penguasaan konsep mengenai materi yang telah diajarkan.Tahapan-tahapan inkuiri yang dilakukan dapat dilihat pada Gambar 2 (Maharta et al., 2016).

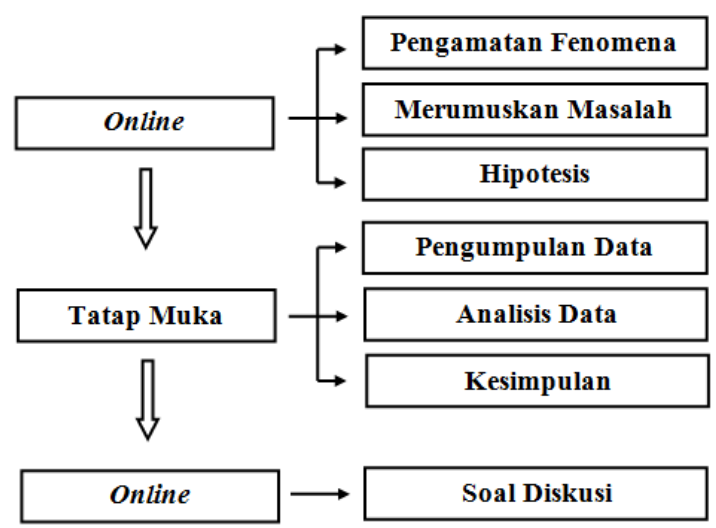

Gambar 2. Tahapan Inkuiri Pada Blended Learning

Poses pengimplementasian blended learning tidak terjadi begitu saja, bahwa dalam menerapkannya terdapat beberapa aspek yang menjadi pertimbangan yaitu karakteristik tujuan pembelajaran yang ingin kita capai, aktifitas pembelajaran yang relevan serta memilih dan menentukan aktifitas mana yang relevan dengan konvensioanal dan aktifitas mana yang relevan untuk online learning (Prayitno, 2013).

Handout berisi materi-materi sebagai bekal awal peserta didik dalam proses pembelajaran. Selanjutnya soal latihan, dibuat dengan tujuan agar peserta didik belatih soal-soal yang berkaiatan dengan kegiatan pembelajaran yang telah dilakukan. Terakhir yang dikembangkan adalah kelas online, yang digunakan sebagai wadah ketika melakukan kegiatan pratatap muka dan pasca tatap muka.

Pada kelas online yang didesain oleh guru, terdapat LKPD, handout dan soal latihan yang dapat diakses oleh peserta didik kapan pun dan dimana pun. Desain kelas online atau strukur isi kelas online dapat dilihat pada Gambar 3. 


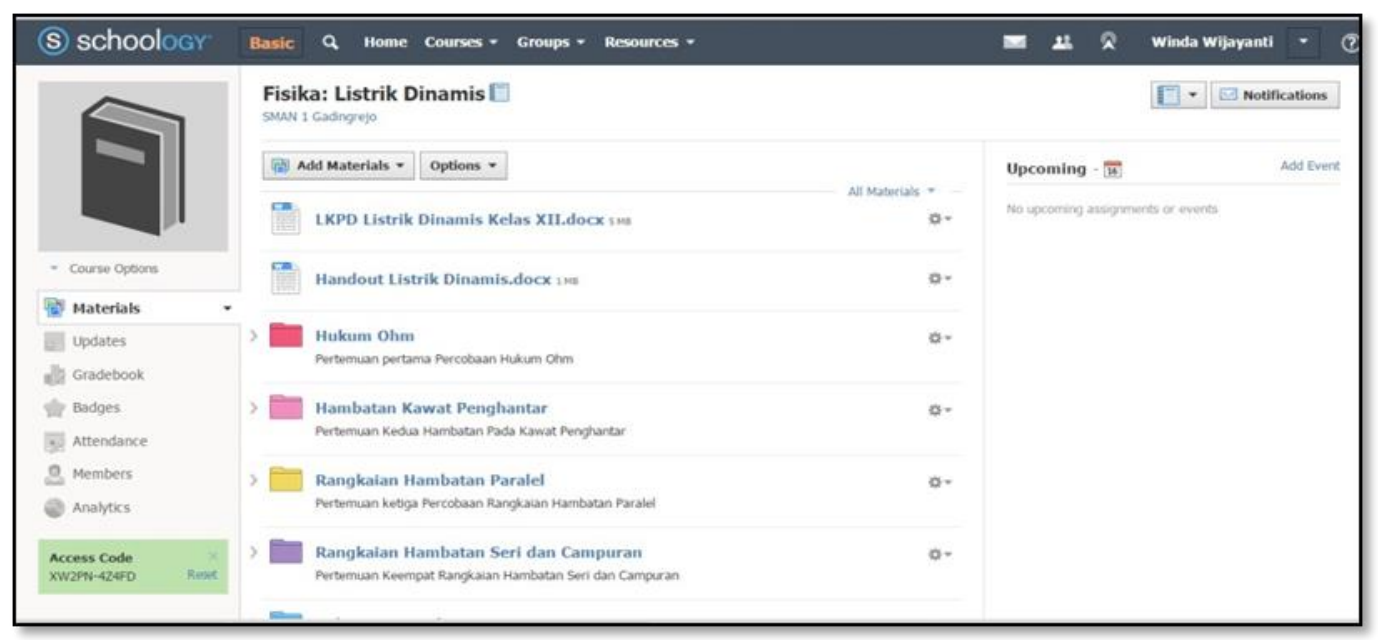

Gambar 3. Struktur Isi Kelas Online

\section{Pengembangan Produk}

Pengembangan produk yang dilakukan berupa pengujian terhadap produk, yaitu uji validasi ahli dan uji kepraktisan. Pada uji validasi ahli dilakukan oleh dua orang ahli dari Pendidikan fisika. Pada tahap uji validasi ahli terdapat beberapa saran perbaikan yang diberikan oleh kedua ahli. Saran perbaikan yang diberikan dapat dilihat pada Tabel 6 .

Tabel 6. Rangkuman Saran Perbaikan Pada Uji Validasi

\begin{tabular}{|c|c|c|c|}
\hline \multirow{2}{*}{ No } & \multirow{2}{*}{$\begin{array}{c}\text { Perangkat } \\
\text { Pembelajaran }\end{array}$} & \multicolumn{2}{|c|}{ Saran Perbaikan } \\
\hline & & Ahli 1 & Ahli 2 \\
\hline 1 & $\begin{array}{l}\text { Silabus } \\
\text { Pembelajaran }\end{array}$ & $\begin{array}{l}\text { Mencantumkan kegiatan pembelajar- } \\
\text { an pada setiap indikator sebagai } \\
\text { upaya pencapaian indikator }\end{array}$ & Memperbaiki format silabus \\
\hline 2 & RPP & $\begin{array}{l}\text { Mencantumkan kegiatan pembelajar- } \\
\text { an untuk mencapai KI } 1 \text { dan KI } 2 \\
\text { Mengonsistenkan tipe blended } \\
\text { learning yang digunakan yaitu online } \\
\text { - tatap muka - online. }\end{array}$ & $\begin{array}{l}\text { Mencantumkan KI } 1 \text { dan KI } 2 \\
\text { pada RPP }\end{array}$ \\
\hline 3 & $\begin{array}{l}\text { Instrumen } \\
\text { Penilaian } \\
\text { Sikap dan } \\
\text { Keterampilan }\end{array}$ & $\begin{array}{l}\text { Mencantumkan sumber penilaian } \\
\text { kualitatif yang digunakan }\end{array}$ & \\
\hline 4 & LKPD & $\begin{array}{l}\text { Merapkan tipe blended learning yang } \\
\text { digunakan pada setiap kegiatan yang } \\
\text { dilakukan }\end{array}$ & $\begin{array}{l}\text { Mencantumkan tujuan } \\
\text { pembelajaran padaLKPD }\end{array}$ \\
\hline 5 & Handout & $\begin{array}{l}\text { Menambahkan persamaan Hukum } \\
\text { Ohm pada materi Hukum Ohm }\end{array}$ & - \\
\hline 6 & $\begin{array}{l}\text { Soal } \\
\text { penguasaan } \\
\text { konsep }\end{array}$ & Memperbaiki soal nomor 10 dan 16 & - \\
\hline
\end{tabular}

Berdasarkan hasil uji validasi produk, selanjutnya dilakukan perbaikan perangkat pembelajaran blended learning berbasis LMS sesuai dengan saran perbaikan. Kemudian produk yang telah diperbaiki diberikan kembali pada kedua ahli dan mulai diberikan penilaian pada setiap aspek yang dikembangkan. Penilaian yang diberikan oleh kedua ahli pada perangkat pembelajaran yang dikembangkan dapat dilihat pada Tabel 7. 
Tabel 7. Hasil Uji Validasi Perangkat Blended Learning oleh Ahli

\begin{tabular}{clccc}
\hline \multirow{2}{*}{ No } & \multirow{2}{*}{ Perangkat Pembelajaran } & \multicolumn{2}{c}{ Persentase Kelayakan } & \multirow{2}{*}{ Kualitas } \\
\cline { 3 - 4 } & & Ahli 1 & Ahli 2 & \\
\hline 1 & Silabus Pembelajaran & $83 \%$ & $83 \%$ & Sangat valid \\
2 & RPP & $86 \%$ & $86 \%$ & Sangat valid \\
3 & Instrumen sikap dan keterampilan & $83 \%$ & $83 \%$ & Sangat valid \\
4 & LKPD & & & \\
& - Isi/materi & $83 \%$ & $86 \%$ & Sangat valid \\
& - Konstruksi & $83 \%$ & $83 \%$ & Sangat valid \\
5 & Handout & - & $88 \%$ & Sangat valid \\
6 & Soal penguasaan konsep & $83,7 \%$ & $84,8 \%$ & Sangat valid \\
\multicolumn{2}{l}{ Rata-rata persentase kelayakan produk } & & & \\
& & &
\end{tabular}

Dari kedua ahli tersebut diperoleh persentase kelayakan sebesar $83,7 \%$ dan $84,8 \%$ untuk setiap aspek perangkat (silabus, RPP, LKPD, handout dan soal evaluasi) yang dikembangkan.

Setelah dikenakan uji validasi ahli terhadap produk yang dikembangkan, kemudian produk dikenakan uji kepraktis- an. Uji kepraktisan di lakukan oleh tiga gurufisika SMA kelas XII yang berasal dari tiga sekolah yang berbeda, yaitu berasal dari SMAN 1 Gadingrejo, SMAN 1 Gedongtataan dan SMA Persada Bandar Lampung. Adapun rangkuman hasil uji praktisi dari ketiga guru tersebut dapat dilihat pada Tabel 8.

Tabel 8. Rangkuman Uji Praktisi

\begin{tabular}{|c|c|c|c|c|c|}
\hline No & Asal Sekolah & $\begin{array}{l}\text { Aspek } \\
\text { Penilaian }\end{array}$ & Saran Perbaikan & $\begin{array}{l}\text { Skor } \\
\text { Rata- } \\
\text { rata }\end{array}$ & Kualitas \\
\hline 1 & $\begin{array}{l}\text { SMA N } 1 \\
\text { Gadingrejo }\end{array}$ & Handout & $\begin{array}{lrr}\begin{array}{l}\text { Menambahkan } \\
\text { handout contoh }\end{array} & \text { soal pada } \\
\text { mempungai beberapa } & \text { referensi } \\
\text { untuk mengerjakan soal. } & \end{array}$ & 85 & $\begin{array}{l}\text { Sangat } \\
\text { Baik }\end{array}$ \\
\hline \multirow[t]{2}{*}{2} & \multirow[t]{2}{*}{$\begin{array}{l}\text { SMA N } 1 \\
\text { Gedongtataan }\end{array}$} & LKPD & $\begin{array}{l}\text { Menyesuaikan alokasi waktu } \\
\text { dengan tingkat kesulitan materi. }\end{array}$ & 80 & Baik \\
\hline & & Handout & $\begin{array}{l}\text { Menambahkan contoh soal } \\
\text { sehingga tujuan pembelajaran dapat } \\
\text { tercapai dengan baik. }\end{array}$ & & \\
\hline \multirow[t]{3}{*}{3} & \multirow[t]{3}{*}{$\begin{array}{l}\text { SMA Persada } \\
\text { Bandar } \\
\text { Lampung }\end{array}$} & RPP & $\begin{array}{l}\text { Menambahkan indiktor pada RPP } \\
\text { pertama hingga ranah kognitif C4, } \\
\text { supaya KD tercapai. }\end{array}$ & 86,7 & $\begin{array}{l}\text { Sangat } \\
\text { Baik }\end{array}$ \\
\hline & & LKPD & $\begin{array}{l}\text { Mengganti desain cover LKPD } \\
\text { kerena kurang mencerminkan } \\
\text { listrik dinamis. }\end{array}$ & & \\
\hline & & \multicolumn{2}{|c|}{ Rata-Rata Skor ketiga guru } & 83,9 & $\begin{array}{l}\text { Sangat } \\
\text { Baik }\end{array}$ \\
\hline
\end{tabular}

Berdasarkan hasil uji praktisi terhadap produk perangkat blended learning, selanjutnya dilakukan perbaikan sesuai dengan saran perbaikan. Kemudian dilakukan analisis hasil penskoran yang diberikan oleh para penguji praktisi dan diperoleh rata-rata skor 83,9 .

\section{Pembahasan}

Tujuan utama penelitian pengembangan ini adalah untuk menghasilkan perangkat blended learning berbasis LMS dengan model pembelajaran inkuiri pada materi listrik dinamis. Hal ini dilakukan sebagai upaya 
untuk memberikan alternatif sistem pembelajaran yang dapat diterapkan oleh guru yang berguna untuk meningkatkan keterampilan TIK peserta didik dan memberikan solusi bagi guru yang kekurangan waktu dalam pe-nyampaian materi listrik dinamis, serta mengatasi kesulitan peserta didik dalam pembelajaran fisika khususnya materi listrik dinamis.

Perangkat blended learning ini dapat digunakan secara mandiri. Perangkat tersebut meliputi RPP, Silabus, LKPD, handout, soal latihan dan kelas online learning. Aspek perangkat blended learningyang dikembangkan disusun dengan langkah-langkah inkuiri, yaitu orientasi, merumuskan masalah, hipotesis, mengumpulkan data, menganalisis data dan membuat kesimpulan.

RPP dan silabus yang dikembangkan oleh peneliti yang bertujuan untuk dijadikan guru sebagai pedoman dalam melaksanakan pembelajaran. kemudian LKPD dikembangkan dengan tujuan sebagai salah satu panduan siswa dalam melaksanakan pembelajaran. LKPD yang dikembangkan juga didesain sebaik mungkin, sehingga siswa tertarik untuk mengikuti pembelajaran. Terdapat siswa yang berpendapat bahwa penggunaan LKPD sangat menarik, hal tersebut sesuai dengan hasil penelitian Latifah et al., (2016).

Pada LKPD diberikan gambaran desain pembelajaran, sehingga siswa tidak bingung dalam menggunakan LKPD. Seperti yang telah diulas sebelumnya bahwa LKPD tersebut dibagi atas 5 kegiatan yang dibagi atas tiga kegiatan pokok pada setiap kegiatannya, yaitu online - tatap muka - online. Peneliti juga mengembangkan handout yang dapat digunakan siswa sebagai bahan bacaan sebelum pembelajaran dimulai. Pada handout, diberikan contoh soal pada setiap submateri yang ada. LKPD dan handout yang telah disebutkan diatas juga dikemas dalam kelas online. Kelas online dibuat untuk melaksanakan tahap online sebelum tatap muka dan online setelah tatap muka. Pada setiap kegiatan online juga tersedia kolom komentar yang dapat dijadikan siswa sebagai penyampaian pendapat (membuat rumusan masalah, hipotesis dan mendiskusikan permasalahan). Kelas online. Juga didukung dengan adanya soal-soal latihan. soal latihan diberikan dengan 5 kali pengulangan pengerjaan, dengan sistem random. Dimana pada proses pengerjaan pertama, susunan soal akan berbeda dengan proses pengerjaan kedua, ketiga dan seterusnya.

Setiap aspek perangkat yang dikembangkan memiliki keterkaitan satu sama lain. Salah satunya video pengamatan fenomena tersedia pada kelas online, digunakan untuk merumuskan masalah dan mengajukan hipotesis yang nantinya akan dituliskan pada LKPD.

Setelah produk selesai dibuat maka selanjutnya produk siap untuk diuji. pada proses pengujiannya, produk dikenakan uji validasi ahli (dosen) dan uji praktisi (guru fisika).

Tujuan dari uji validasi oleh ahli yaitu untuk mendapatkan penilian sehingga tingkat kevalidan produk dapat diketahui serta mengetahui kelemahan produk dengan meminta saran perbaikan dari validator untuk penyempurnaan produk yang dikembangkan. Selanjutnya saran dari validator akan digunakan sebagai acuan dalam merevisi produk agar menjadi lebih baik (Warsita, 2008).

Proses validasi terhadap produk yang dikembangkan oleh peneliti dilakukan sebanyak dua kali, hingga akhirnya validator menyatakan bahwa produk yang dikembangkan layak digunakan dan diujicobakan kepada siswa. Pada proses validasi produk yang pertama, peneliti memperoleh banyak saran perbaikan dari kedua validator. Saran perbaikan tersebut dapat dilihat pada Tabel 6. Setelah produk diperbaiki, selanjutnya produk kembali diberikan pada kedua validator dan mulai diberikan penilaian. Dari proses penilaian 
diperoleh persentase kelayakan pada setiap aspek yang dikembangkan yaitu sebesar $83,7 \%$ dan $84,8 \%$ dengan interpretasi sangat valid dan layak digunakan.

Setelah uji validasi ahli selesai, produk dikenakan uji praktisi dilakukan oleh tiga guru fisika kelas XII dari SMA yang masing-masing berasal dari SMA $\mathrm{N} 1$ Gadingrejo, SMA N 1 Gedongtataan dan SMA Persada Bandar Lampung. Uji praktisi dimaksudkan untuk mengetahui tingkat kepraktisan (kemudahan, keterbantuan, dan kesesuaian) dari produk yang dikembangkan. Perolehan skor dari masing-masing guru sebesar $85 ; 80$; dan 86,7 . Sehingga rata-rata skor dari ketiga guru adalah 83,89 dengan interpretasi sangat praktis dan dengan rekomendasi layak digunakan.

Produk yang dihasilkan ini memiliki kelebihan dan kekurangan jika diimplementasikan dalam pembelajaran. Kelebihan dari perangkat ini antara lain: (1) Perangkat pembelajaran yang disertai dengan kegiatan pengamatan fenomena yang diberikan melalui video akan membuat ketertarikan siswa bertambah dan aktifitas siswa pun akan semakin baik. Hal tersebut sesuai dengan penelitian yang dilakukan oleh Diani (2015), bahwa perangkat pembelajaran yang dikembangkan efektif, ditunjukkan dengan peningkatan kompetensi dan aktifitas siswa. (2) Peserta didik dapat berlatih soal latihan berkali-kali pada kelas online namun dengan sistem soal yang dirandom, (3) Pada latihan soal juga diberi feedback jika jawaban benar maupun salah, (4) Disediakan soal penguasaan konsep di LKPD sebelum didiskusikan pada kelas online, dan (5) Peserta didik dapat mengakses LKPD dan handout dimana pun dan kapan pun karena selain diberi hard file LKPD dan handout juga disediakan soft file pada Schoology, (6) Melatih kemampuan siswa dalam menggunakan TIK dan memanfaatkan internet secara maksimal. Hal tersebut sejalan dengan pendapat Zaka (2013) bahwa pembelajaran blended learning dapat mengembangkan keterampilan siswa dalam menggunakan ICT.

Sesuai dengan tuntutan abad 21 bahwa lulusan yang dihasilkan proses pembelajaran harus memiliki keterampilan menggunakan TIK. Hal itu menjadikan blended learning berguna pada masa yang akan datang. Mengingat pergeseran bagaimana peserta didik mencari informasi dari waktu ke waktu, yang dulu hanya dapat mencari informasi melalui buku saja kini proses pencarian informasi dapat dilakukan dengan memanfaatkan fasilitas internet. Faktor lain yang mendukung adalah infrastruktur IT juga semakin baik seiring dengan perkembangan zaman dan paradigma, pola pikir serta psikologi peserta didik yang mulai berubah.

Selain kelebihan, perangkat blended learning ini juga memiliki beberapa kekurangan, yaitu dalam mengakses kelas online dibutuhkan jaringan internet yang memadai, dibutuhkan konektivitas yang baik, dan belum diketahui keefektifan perangkat yang dikembangkan karena belum dilakukan uji lapangan. Dengan begitu terdapat peluang untuk dilakukan uji lanjutan.

\section{SIMPULAN}

Simpulan dari penelitian ini adalah: (1) Telah dihasilkan perangkat blended learning berbasis LMS dengan model inkuri pada materi listrik dinamis, perangkat yang dihasilkan berupa silabus, RPP, LKPD, handout, soal latihan dan kelas online; (2) Hasil uji validasi ahli menunjukkan bahwa produk yang dikembangkan memiliki kualitas sangat valid dan layak digunakan dengan perolehan persentase kelayakan pada setiap aspek perangkat yang dinilai yaitu sebesar 83,7\% dan 84,8\%; (3) Hasil uji kepraktisan yang diperoleh dari penilian tiga guru fisika kelas XII dari SMA yang berbeda berturut-turut adalah 85,80 dan 
86,67. Sehingga diperoleh rerata skor sebesar 83,89 dengan interpretasi sangat praktis dan layak digunakan.

\section{DAFTAR PUSTAKA}

Amiroh. (2013). Antara Schoologi, Moddle dan Edmodo.Retrieved from http://amiroh.web.id/antaramoodle-edmodo-dan-schoology/.

Anam, K. (2016). Pembelajaran Berbasis Inkuiri Metode dan Aplikasi. Yogyakarta: Pustaka Pelajar.

Arikunto, S. (2013). Prosedur Penelitian: Suatu Pendekatan Praktik. Jakarta: Rineka Cipta.

Diani, R. (2015). Pengembangan Perangkat Pembelajaran Fisika Berbasis Pendidikan Karakter Dengan Model Problem Based Instruction. Jurnal Ilmiah Pendidikan Fisika Al-Biruni. 4(2), 243-255.

Gall, M. D., Gall, J. P. \& Brog, W. R. (2003). Education Research an Introduction, Seventh Edition. Boston: Pearson Education, Inc.

Hamruni. (2011). Strategi Pembelajaran. Yogyakarta: Insan Mandiri.

Hermawanto., Kusairi, S., \& Wartono. (2013). Pengaruh Blended Learning terhadap Penguasaan Konsep dan Penalaran Fisika Peserta Didik Kelas X. Jurnal Pendidikan Fisika Indonesia. 9, 67-76.

Ibrahim, M. (2010). Model Pembelajaran Inkuiri. Retrieved from http://fisika21.wordpress.com.

Justice, C., Rice, J., Roy, D., Hudspith, B., \& Jenkins, H. (2009). InquiryBased Learning in Higher Education: Administrators' Perspectives on Integrating Inqury Pedagogy into the Curriculum. Higher Education, 58(6), 841-855.

Latifah, S., Setiawati, E., Basith, A. (2016). Pengembangan Lembar Kerja Peserta Didik (LKPD) Berorientasi Nilai-Nilai Agama
Islam Melalui Pendekatan Inkuiri Terbimbing Pada Materi Suhu dan Kalor. Jurnal Ilmiah Pendidikan Fisika Al-Biruni, 5(1), 43-52.

Maharta, N., Suana, W., \& Nyeneng, I. D. P. (2016). Pengembangan Program Blended Learning Berbasis Inkuiri dengan Learning Management Systempada Materi Kelistrikan SMA. Proposal Penelitian Produk Terapan (Tidak Dipublikasikan). Universitas Lampung.

Mahnegar, F. (2012). Learning Management System. International Journal of Business and Social Science, 3(12), 144-150.

Partnership for 21st Century Skills. (2007). Beyond the Three Rs: Voter Attitudes Toward 21st Century Skills. Tucson, AZ: Author.

Prayitno, W. (2013). Implementasi Blended Learning Dalam Pembelajaran Pada Pendidikan Dasar dan Menengah.

Purnomo, A., Rahmawati, N., \& Aristin, N. F. (2016). Pengembangan Blended learning Pada Generasi Z. Jurnal Teori dan Praktis Pembelajaran IPS, 1(1), 70-76.

Sugiyono. (2010). Metode Penelitian Kuantutatif, Kualitatif \& RND. Bandung: Alfabeta.

Suradnya, L. S. A. (2016). Modul Interaktif dengan Program LCDS untuk Materi Cahaya dan Alat Optik. Jurnal Pembelajaran Fisika. 4(2), 35-46.

Sutisna, A. (2016). Pengembangan Model Pembelajaran Blended Learning pada Pendidikan Kesetaraan Program Paket C dalam Meningkatkan Kemandirian Belajar. Jurnal Teknologi Pendidikan. 18 (3). 156-168.

Suyanto, E.,\& Sartinem. (2009). Pengembangan Contoh Lembar Kerja Fisika Siswa dengan Latar Penuntasan Bekal Awal Ajar Tugas 
Studi Pustaka dan Keterampilan Proses untuk SMA Negeri 3 Bandar Lampung. Prosiding Seminar Nasional Pendidikan 2009. Bandar Lampung: Universitas Lampung. Warsita, B. (2008). Teknologi Pembelajaran: Landasan dan Aplikasinya. Jakarta: Rineka Cipta.
Widyoko, S. E. P. (2009). Evaluasi Program Pembelajaran. Yogyakarta: Pustaka Pelajar.

Yilmaz, M. B., \& Orhan, F. (2010). High School Students Educational Usage of Internet and Their Learning Approaches. World Journal on Education Tecnology, 2(2), 100112. 